\title{
Herd dynamics, production and marketing constraints in the commercialization of cattle across Nguni Cattle Project beneficiaries in Eastern Cape, South Africa
}

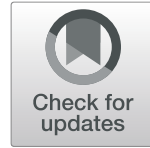

N. Malusi ${ }^{1,2}$, A. B. Falowo ${ }^{1,3}$ and E. M. Idamokoro ${ }^{1,4^{*}}$

\begin{abstract}
This paper examines the challenges restricting the commercialization of cattle across Nguni Cattle Project beneficiaries in South Africa. Data were collected from one hundred and twenty (120) Nguni cattle beneficiaries using a structured questionnaire across six district municipalities of the Eastern Cape Province. Results revealed that majority of Nguni cattle beneficiaries were males, were above 60 years old, and have received formal training in livestock farming. Most of the beneficiaries reared cattle with other livestock species, with $45 \%$ owned non-descript breeds, 33\% Nguni and 22\% other breeds such as Bonsmara and Brahman. About 79.2\% of the beneficiaries practised continuous grazing while $52.5 \%$ give their cattle supplements, with most commonly (48\%) using rivers as the source of water. Most beneficiaries (38.4\%) reported diseases as main production constraints, followed by stock theft (27.5\%) and feed shortages (22.5\%). Furthermore, results showed that $80.8 \%$ of beneficiaries market one to 10 cattle per year, $64.8 \%$ adult cattle (2+ years old) and 35.2\% weaners (8 months to 1 year). Most beneficiaries (78.7\%) used private marketing channels to sell their animals, while $4.3 \%$ used abattoirs. Factors identified as the main market constraints included low cattle numbers (41.7\%), inability to meet formal market standards (25\%) and inadequate government support. There was a strong association between formal livestock training and cattle marketing attributes as well as production constraints. In conclusion, more emphasis should be given to improve cattle production and commercialization through provision of more cattle, livestock trainings and market services to communal farmers.
\end{abstract}

Keywords: Herd size, Production and marketing constraints, Government support, Indigenous cattle breed

\section{Introduction}

South Africa has a total of 13.9 million cattle (Statistics South Africa (STATS SA) 2016), of which $60 \%$ are owned by commercial farmers while emerging and communal farmers own 40\% (Department of Agriculture Forestry and Fisheries (DAFF) 2018). It has been reported that land size is one of the determinants which

\footnotetext{
* Correspondence: mondayidamokoro@gmail.com; eidamokoro@ufh.ac.za ${ }^{1}$ Department of Livestock and Pasture Science, University of Fort Hare, Alice, Eastern Cape 5700, South Africa

${ }^{4}$ Agricultural and Rural Development Research Institute, University of Fort Hare, Private Bag X1314, Alice 5700, South Africa

Full list of author information is available at the end of the article
}

differentiate smallholder and commercial farmers. However, Kirsten and Sihlobo (2019) argued that the farm's turnover (level of net income) determines the herd size of the farm, irrespective of the land size. Therefore, commercial farmers are those with high turnover as they sell a significantly higher number of animals, therefore have more profit as compared to smallholder farmers. The communal farmers and poorresourced farmers rear indigenous beef cattle on natural pastures (Bester et al. 2001) to meet their multiple needs such as milk, manure (Ndlovu et al. 2009; Masikati 2011), meat, hides (Mavedzenge et al. 2006), 
employment opportunities (Tavirimirwa et al. 2013), socio-cultural functions (Maburutse et al. 2012), income and investment (Ndebele et al. 2007). In addition, the Integrated Sustainable Rural Development Strategy (ISRD S) (2004) and Coetzee et al. (2006) highlighted that South African livestock production has a great potential in decreasing the rate of food scarcity and poverty in communal areas.

In most countries, indigenous cattle breeds have been regarded to be of lower market value than imported breeds because of their small mature weight. These assumptions have resulted in reduced use of indigenous breeds, while increasing the use of exotic breeds. In contrast to these assumptions, exotic breeds are susceptible to harsh environmental conditions such as tick-borne diseases, feed scarcity and poor feed quality that are prevalent in most communal areas (Muchenje et al. 2008a). Exotic breeds require a high level of dietary supplementation, especially during the dry season, to maintain body condition. Therefore, indigenous breeds such as Nguni have been reintroduced to most communal areas due to their adaptive qualities, including resistance to parasites, and production of high-quality beef comparable to imported breeds (Muchenje et al. 2008b).

Development programmes have been initiated to repopulate Eastern Cape with indigenous breeds in communal areas. Among other development programmes, the Nguni Cattle Project has been established where a number of Nguni heifers and bulls are distributed to selected communities so as to build the nucleus herd (Fuller 2006). The first programme began in 1998 which was specifically aimed at reintroducing the Nguni breed in the Eastern Cape (Musemwa et al. 2008). The Eastern Cape Nguni Cattle Project is the partnership of the University of Fort Hare (UFH), the Eastern Cape Department of Rural Development and Agrarian Reform (ECDRDAR) and Industrial Development Cooperation (IDC). The project was established due to the high performance of Nguni cattle with adaptive traits to harsh environments. According to the report from University of Fort Hare Nguni Cattle Project (Fuller 2006), farmers in selected areas are provided with 10 in-calf heifers and two bulls with the aim of building a nucleus herd. After 5 years, the community gives back 10 heifers and two bulls to the project, which are then passed to another community (Raats et al. 2004). The requirements for the project are: the grazing area should be fenced and practising rotational grazing (Mapiye et al. 2007) and the existing bulls in the community should be replaced by registered Nguni bulls, either by castration or culling (Musemwa et al. 2008).

The major role of the project is to develop a niche market for Nguni products (beef and skins) and to introduce communal farmers to global markets through production and product processing (Raats et al. 2004). The project also aims to train farmers on cattle management. The project development committee has the responsibility of training farmers, redistribution of animals and development of infrastructures such as holding pens (Musemwa et al. 2008).

Irrespective of the benefits contributed by cattle, communal farmers face a significant number of challenges that restrict them from generating income from their livestock. These challenges include insufficient access to land and water, lack of access to market channels, poor rangeland management, lack of feed resources, animal diseases, smaller herd size and stock theft (Bester et al. 2001; Musemwa et al. 2008). The poor growth rates of cattle in communal areas are mainly due to the lack of controlled breeding which leads to inbreeding (Mashoko et al. 2007; Mueller et al. 2015). Production of non-descript genotypes has resulted in unidentified genetic characterization. Other factors such as disease, low fertility (because of poor nutrition and the prevalence of tick-borne diseases), insufficient access to veterinary services and changes in feed quality and quantity due to seasonal deficiency (especially in second half of the dry season) have been reported to lower the performance of communal beef cattle in South Africa (Mavedzenge et al. 2006). In addition, Lapar et al. (2003) reported that challenges limiting those smallholder farmers were insufficient capital resources, which included financial and physical resources, intellectual capital resources, education and extension.

Cattle marketing for smallholder farmers in South Africa is also affected by low off-take, poor cattle conditions and inadequate cattle numbers to offset pre-slaughter transaction costs and fulfil the formal market demand (Musemwa et al. 2010). Coetzee et al. (2006) highlighted that the formal markets selling young and well-conditioned animals disadvantage smallholder farmers who market old and emaciated animals. Bahta and Bauer (2007) also found that poor access to market information, lack of market access, poor infrastructure and tacit knowledge are marketing constraints affecting communal farmers. The beneficiaries of the Nguni Cattle Project have been experiencing the challenge of claims that Nguni cattle have small body weights, thereby reducing their selling price compared to other breeds. By implication, all these factors directly impact on the commercialization of cattle for smallholders. The objective of the study was, therefore, to determine the impact of cattle herd dynamics on the commercialization of cattle across Nguni Cattle Project beneficiaries in Eastern Cape, South Africa, through a structured survey. 


\section{Materials and methods}

\section{Experimental site description}

The study was conducted in six district municipalities of the Eastern Cape Province in South Africa, namely Amathole, O R Tambo, Alfred Nzo, Joe Gqabi, Chris Hani and Sarah Baartman where the Nguni Cattle Project has been initiated and nurtured. The geographical coordinates and pedo-climatic conditions of the study areas are shown in Table 1 . The permission to carry out the study was approved and issued by the University of Fort Hare Ethical Clearance committee.

\section{Data collection}

Before commencement of data collection, piloting was done in which 10 farm aid workers in the University of Fort Hare Farm, who are also farmers, were randomly selected for interviews with questionnaires to be used for the study target group of Nguni Cattle Project beneficiaries. The pilot aimed to ensure that farmers do understand the concept and the objectives of the study. The pre-testing was also conducted for the betterment of questioning style and ensuring the time duration of the interviews.

The data was collected from questionnaires of 120 surveyed beneficiaries of the Nguni Cattle Project, out of a total of about 180 beneficiaries that are still active in cattle farming. The Nguni Cattle Project is divided into two enterprises, the group-owned (small-scale farms in Land Redistribution and Agriculture Development farms) and the village-owned (communities). The Nguni Project is a partnership of the government Department of Rural Development and Agrarian Reform and University of Fort Hare, South Africa. The Nguni Cattle Project beneficiaries in each municipality were identified through the assistance of Eastern Cape Nguni officials in University of Fort Hare. Data was collected from 72 beneficiaries within the group-owned enterprise and 48 beneficiaries within the village-owned enterprise. The data was collected in face-to- face interviews, recorded on the questionnaires which comprised questions on household demographic information, livestock ownership, cattle production and governmental assistance. The enumerators who assisted in data collection understood IsiXhosa and English, since most respondents were Xhosaspeaking and few needed explanations in English. The enumerators were trained on how to approach and record the information obtained from respondents.

\section{Statistical analysis}

The data collected from the beneficiaries of the Eastern Cape Nguni Cattle Project was analysed using SPSS package (version 2016). Frequencies were analysed of the demographic characteristics, cattle herd size ownership, cattle breeds, cattle supplementation, types of water source, types of veterinary services, cattle production and marketing constraints and government support. The chi-squared test was used to determine the degree of association between categorical variables; demographic information, and cattle production and marketing among the beneficiaries of the Nguni Cattle Project.

\section{Results and discussion \\ Demographic characteristics of Nguni Cattle Project beneficiaries}

The results show that, of the 120 interviewed Nguni farmer beneficiaries, $85.8 \%$ were males, while only $14.2 \%$ were female (Table 2). This accords with the results of Gwala et al. (2016) who found that in the agricultural sector in South Africa, male farmers dominate. Among the sample, $60.8 \%$ of the beneficiaries were above 60 years followed by $51-60,41-50$ and $31-40$ with $28.3 \%$, $8.3 \%$ and $2.5 \%$ respectively. Chris Hani district municipality had the highest number of beneficiaries (84.6\%) above 60 years, while Joe Gqabi had the lowest number of beneficiaries (40\%) at the same age range. Majority (94.2\%) of the beneficiaries interviewed were married, while $5 \%$ and $0.8 \%$ of the beneficiaries were widowed and single, respectively. About $47.5 \%$ of the beneficiaries

Table 1 The geographical coordinates and pedo-climatic conditions of the study areas

\begin{tabular}{llllll}
\hline District & Geographical coordinates $^{*}$ & Rangeland type & Annual rainfall $(\mathbf{m m})$ & Mean annual temperature $\left({ }^{\circ} \mathrm{C}\right)$ & Altitude $(\mathrm{m})$ \\
\hline Alfred Nzo & $30.54^{\circ} \mathrm{S}, 28.85^{\circ} \mathrm{E}$ & Sour & $600-950$ & $14-15$ & $600-1400$ \\
Amathole & $32.58^{\circ} \mathrm{S}, 27.36^{\circ} \mathrm{E}$ & Sweet & $400-700$ & $15-20$ & $400-700$ \\
Joe Gqabi & $30.98^{\circ} \mathrm{S}, 26.98^{\circ} \mathrm{E}$ & Sweet-sour & $400-700$ & $12-16$ & $1100-1600$ \\
O R Tambo & $31.46^{\circ} \mathrm{S}, 29.23^{\circ} \mathrm{E}$ & Sweet-sour & $450-750$ & $17-18$ & $600-850$ \\
Chris Hani & $31.87^{\circ} \mathrm{S}, 26.79^{\circ} \mathrm{E}$ & Sweet-sour & $400-700$ & $12-16$ & $400-1450$ \\
Sarah Baartman & $33.57^{\circ} \mathrm{S}, 25.36^{\circ} \mathrm{E}$ & Sour & $600-945$ & $12-14$ & $800-1350$ \\
\hline
\end{tabular}

Source: Mucina and Rutherford (2006). Sweet rangeland occurs in areas with low water supply and where parent material gives rise to soils with a high base status. This veld type is characterized by production of palatable grazing of predominantly annual grasses (Ellery et al. 1995). Sour rangeland occurs in areas with high water supply and where parent material gives rise to soils with a low base status. This veld type is largely covered with coarse seasonal perennial grasses and affords inferior grazing (Ellery et al. 1995)

*Geographical coordinates: GPS coordinates of the main Town (seat) in each district 
Table 2 Demographic characteristics of the Nguni Cattle Project beneficiaries (No. $=120$ )

\begin{tabular}{ll}
\hline Demographic characteristics & Frequency (\%) \\
\hline Gender & $103(85.8)$ \\
Male & $17(14.2)$ \\
Female & \\
Age (years) & $3(2.5)$ \\
$31-40$ & $10(8.3)$ \\
$41-50$ & $34(28.3)$ \\
$51-60$ & $73(60.8)$ \\
$>60$ & \\
Marital status & $113(94.2)$ \\
Married & $1(0.8)$ \\
Single & $6(5)$ \\
Widowed & \\
Level of education & $6(5)$ \\
None & $57(47.5)$ \\
Grades 1-7 & $45(37.5)$ \\
Grades 8-12 & $12(10)$ \\
Tertiary & \\
Primary source of income & $10(8)$ \\
Salary & $66(55)$ \\
Old pension government grant & $3(2)$ \\
Crops & $13(11)$ \\
Remittance & $20(17)$ \\
Government social grant & \\
Livestock & \\
\hline & \\
\hline
\end{tabular}

had primary education (Grades 1-7) followed by those with secondary education (Grades 8-12) with 37.5\%. These results agree with the findings of Gwala et al. (2016) that about 59\% of Nguni beneficiaries in two villages of Eastern Cape Province had the primary education (Grades 1-7). The results also reveal that the majority (55\%) of the beneficiaries mainly depend on social grants and old age pensions from the state. This is in agreement with the finding of Molefi and Mbajiorgu (2016) who found that about $45 \%$ of the respondents in Mpumalanga mainly depended on pensions as their primary source of income.

\section{Herd dynamics and production system of Nguni cattle farmers}

The majority of beneficiaries (73.3\%) of the Nguni Cattle Project reared cattle along with other livestock species, while only $26.7 \%$ reared only cattle (Table 3 ). The other species owned by the beneficiaries include sheep, goats and horses. The majority (53.3\%) of the beneficiaries have cattle herd sizes within the range of 11-50 head,
Table 3 Herd dynamics and production system of Nguni cattle farmers (no. $=120)$

\begin{tabular}{|c|c|c|}
\hline \multirow[t]{2}{*}{ Parameters } & \multicolumn{2}{|c|}{ Number of beneficiaries } \\
\hline & No & $\%$ \\
\hline \multicolumn{3}{|l|}{ Livestock ownership } \\
\hline Cattle only & 32 & 26.7 \\
\hline Cattle and other species & 88 & 73.3 \\
\hline \multicolumn{3}{|l|}{ Livestock training } \\
\hline Formal training & 60 & 50 \\
\hline Not trained & 60 & 50 \\
\hline \multicolumn{3}{|l|}{ Cattle breed owned } \\
\hline Nguni & 39 & 33 \\
\hline Non-descripts & 54 & 45 \\
\hline Bonsmara & 11 & 9 \\
\hline Brahman & 12 & 10 \\
\hline Others & 4 & 3 \\
\hline \multicolumn{3}{|l|}{ Grazing system practised } \\
\hline Continuous & 95 & 79.2 \\
\hline Rotational & 25 & 20.8 \\
\hline \multicolumn{3}{|l|}{ Feed supplementation type } \\
\hline Supplement & 63 & 52.5 \\
\hline Non Supplement & 57 & 47.5 \\
\hline \multicolumn{3}{|l|}{ Source of drinking water } \\
\hline Dam & 50 & 42 \\
\hline Borehole & 12 & 10 \\
\hline River & 58 & 48 \\
\hline \multicolumn{3}{|l|}{ Source of veterinary services } \\
\hline Veterinary drug supplier & 96 & 80.2 \\
\hline Government veterinary supplier & 24 & 19.8 \\
\hline
\end{tabular}

followed by those who own one to 10 cattle (38.3\%) while $4.2 \%$ of beneficiaries each owned $51-100$ and $100+$ cattle (Table 4). These findings are in line with results by Molefi and Mbajiorgu (2016), that $50 \%$ of beef cattle farmers in Chief Albert Luthuli Local Municipality, Mpumalanga, owned more than 10 cattle. The Chris Hani and Sarah Baartman municipalities had the majority of beneficiaries with small cattle herds of one to 10 head at $53.8 \%$ and $50 \%$ respectively (Table 4 ). The Joe Gqabi municipality had the highest number of beneficiaries $(20 \%)$ who owned more than 100 cattle; this is due to the fact that all of the interviewed beneficiaries in this municipality were land owners. There is a positive relationship between household cattle ownership and land availability. In addition, Tada et al. (2013) found that herd sizes were significantly higher in group-owned enterprises (29.9\%) as compared to village-owned enterprises (23.6\%). Moreover, Pica-Ciamarra et al. (2011) 
Table 4 Cattle herd size owned by the Nguni Cattle Project beneficiaries across six districts

\begin{tabular}{llllllll}
\hline No. of cattle owned & Amathole & OR Tambo & Joe Gqabi & Alfred Nzo & Chris Hani & Sarah Baartman & Total (No.= 120) \\
& No. (\%) & & & & & \\
\hline $1-10$ & $23(38.3)$ & $5(31.3)$ & $0(0)$ & $5(35.8)$ & $7(53.8)$ & $6(50)$ & $46(38.3)$ \\
$11-50$ & $34(56.7)$ & $10(62.4)$ & $2(40)$ & $8(57.1)$ & $5(38.5)$ & $5(41.7)$ & $64(53.3)$ \\
$51-100$ & $2(3.3)$ & $0(0)$ & $2(40)$ & $1(7.1)$ & $0(0)$ & $0(0)$ & $5(4.2)$ \\
$100+$ & $1(1.7)$ & $1(6.3)$ & $1(20)$ & $0(0)$ & $1(7.7)$ & $1(8.3)$ & $5(4.2)$ \\
\hline
\end{tabular}

reported that farmers who mostly participate in the cattle business are those who own large amounts of land.

The Nguni beneficiaries who received formal livestock training such as animal handling, health and nutrition were tied at $50 \%$ with those who never received formal training (Table 3). About $45 \%$ of the beneficiaries owned non-descript cattle, followed by those who owned Nguni with 33\%. Only 3\% of the beneficiaries owned other breeds such as Jersey, Boran and Pinzgauer (Table 3). Tada et al. (2013) reported that communal farmers prefer non-descripts over exotic and local breeds in Eastern Cape Province of South Africa. However, the Nguni Cattle Project beneficiaries are only allowed to cross their Nguni after they have given back the loaned animals after the period of five years, and thereafter they have full control of their remaining herd. The reason for crossbreeding could be due to owners' preference for milk and meat, as Nguni cattle are low milk producers.

Furthermore, it was observed from this study that majority $(79.2 \%)$ of the respondents practised continuous grazing system, while only $20.8 \%$ practised rotational grazing. These results depict that of the 120 interviewed beneficiaries, since $20.8 \%$ owned land for cattle farming (having fenced paddocks), while $79.2 \%$ depend on the community's land. More so, only $52.5 \%$ of beneficiaries were regularly supplementing their cattle, while $47.5 \%$ were not supplementing because of availability of pasture on grazing lands. According to Bester et al. (2001), one of the common features of communal farming in developing countries is rearing indigenous beef breeds on natural pasture without dietary supplementation. The main types of supplements that were regularly used by the interviewed beneficiaries include lucerne, mineral licks and maize. This is similar to the findings of Eugene (2017) who reported that in Nyagatare District of Eastern Province in Rwanda, the majority of cattle farmers used salt lick and vitamins as supplementary sources for their animals.

It was also observed that $48 \%$ of the beneficiaries used flowing rivers as the major source of water for cattle, while others used dams (42\%) and boreholes (10\%) (Table 3). This general trend of water sourcing is similar to reports by Tonamo et al. (2015) that in
Dawuro Zone of southern Ethiopia, the majority of cattle farmers used rivers as sources of water for their animals. The quality of water and the distance travelled to reach water are major concerns. It is known that poor quality of water may lead to pathogens and helminth infestation among the animals, thereby resulting in disease outbreaks and lower productivity (Tonamo et al. 2015). About $80.2 \%$ beneficiaries were using veterinary drug suppliers to access medication for the cattle, while $19.8 \%$ mainly used government veterinary services. The use of government veterinary services means that medication support (both services and products) were from the government and veterinarians from the government assist farmers.

\section{Cattle production constraints faced by the Nguni Cattle Project beneficiaries}

The most common (38.4\%) major constraint listed by the beneficiaries were diseases such as tick-borne diseases (anaplasmosis and heartwater) which commonly cause death of infected animals, followed by stock theft and feed shortage at $27.5 \%$ and $22.5 \%$, respectively (Fig. 1). The results of the current study agrees with Mapiye et al. (2009), Hangara et al. (2011) and Nkonki-Mandleni et al. (2019), who found that diseases and feed shortage (drought) are the highest constraints affecting cattle production of smallholder farmers in South Africa and Namibia. The water shortage was not regarded as a major constraints in all six municipalities.

\section{Cattle marketing by the beneficiaries of the Nguni Cattle Project}

Out of the 120 interviewed Nguni cattle beneficiaries, $78 \%$ claimed to sell cattle as shown in Table 5. Among the remaining beneficiaries (22\%) who were not selling their cattle, they indicated that having few numbers of cattle was one of their main constraints. Some of the beneficiaries reported that they sell crops and other livestock species such as sheep and goats, while using cattle for other household needs such as traditional ceremonies and weddings. This is in line with the findings by Enkono et al. (2013), who reported that mixed farming in Namibia is one of the 


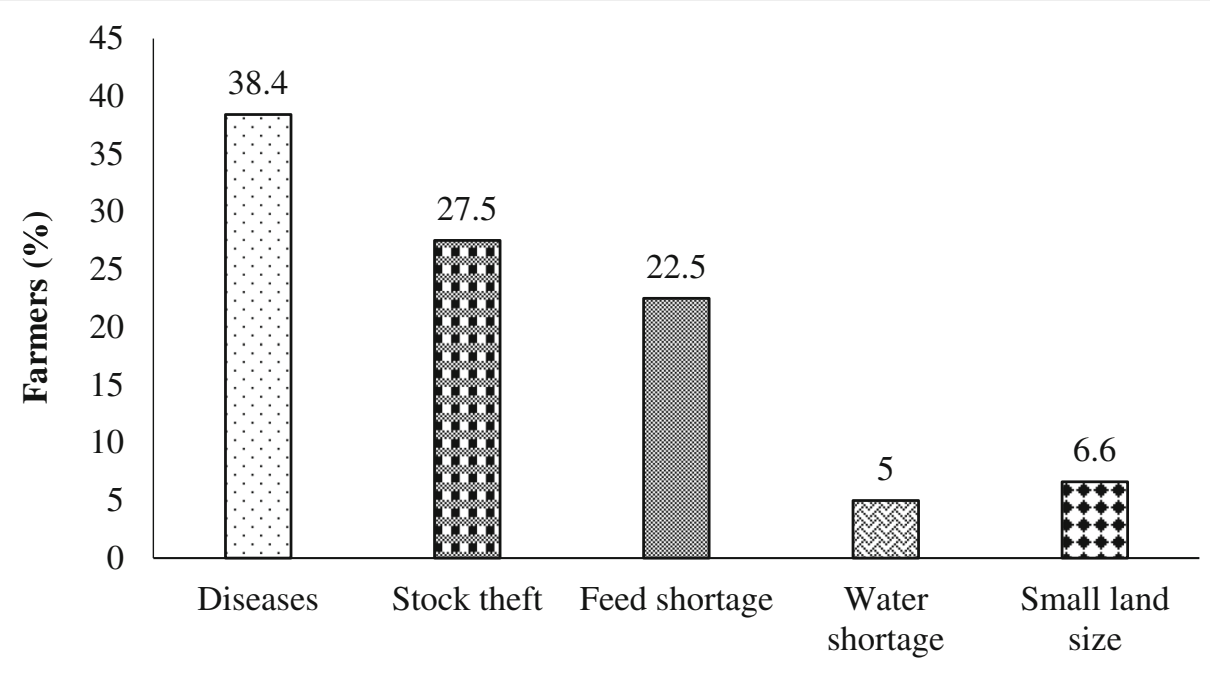

Cattle production constraints

Fig. 1 Cattle production constraints faced by Nguni Cattle Project beneficiaries

important reducing factors for the participation of smallholder farmers in cattle marketing. Of the 78 beneficiaries who were selling cattle, the majority $(80.8 \%)$ were selling one to 10 cattle head (s) per year, followed by those selling 11-20 (13\%) and least with those selling $20+(5 \%)$ cattle heads per year (Table 5). The Sarah Baartman municipality had the highest number (25\%) of beneficiaries who were selling large numbers of cattle $(20+)$ per year, followed by Chris Hani and Amathole with 9.1\% and 4.5\%,

Table 5 Cattle selling by the beneficiaries of the Nguni Cattle Project in Eastern Cape (No. $=120)$

\begin{tabular}{lll}
\hline Parameters & \multicolumn{2}{l}{ Number of beneficiaries } \\
\cline { 2 - 3 } & No. & $\%$ \\
\hline Number of farmer selling cattle & & 78 \\
Yes & 94 & 22 \\
No & 26 & \\
Type of cattle sold $(\boldsymbol{n}=\mathbf{9 4})$ & & 35.2 \\
Weaners & 33 & 64.8 \\
Adult & 61 & \\
Type of market channels $(\boldsymbol{n}=\mathbf{9 4 )}$ & & 4.3 \\
Abattoir & 4 & 8.5 \\
Auction & 8 & 8.5 \\
Feedlot & 8 & 78.7 \\
Sales from other farmers & 74 & \\
Market support from government & \\
Supported & 5 & $\mathbf{9 6}$ \\
Not supported & $\mathbf{1 1 5}$ &
\end{tabular}

respectively (Table 6). According to Enkono et al. (2013), bigger herds had more marketing of cattle. In contrast, the current study show that the Chris Hani and Sarah Baartman municipalities have the highest number of beneficiaries $(53.8 \%$ and $50 \%$ ) respectively owning only one to 10 cattle, indicating few beneficiaries owning large herds (Table 3). However, the two municipalities have the highest number of beneficiaries who sell large numbers from their herds. The possible reason for this is that farmers in these municipalities make use of all the available market channels.

It was also noted that majority (64.8\%) of the Nguni Cattle Project beneficiaries were selling adult cattle $(2+$ years old), while $35.2 \%$ were selling weaners ( 8 months to 1 year). The findings agree with the findings of Coetzee et al. (2006) who reported that the smallholder farmers in Eastern Cape Province of South Africa market old and emaciated animals, which makes it difficult to cope with the requirements of formal markets to sell young cattle. According to Enkono et al. (2013), the majority of communal farmers in Ndiyona constituency of Kavango region in Namibia sell old animals because they use young (especially female) cattle for breeding purposes.

Of all the beneficiaries who were selling cattle, $78.7 \%$ were using private sales (i.e. sales to other farmers) as their market channel, while $8.5 \%$ used auctions and and $8.5 \%$ used feedlots. The abattoir was found to be the least used market channel by the beneficiaries of the Nguni Cattle Project, with $4.3 \%$. These findings are in 
Table 6 Cattle sold by beneficiaries (farmers) per year across six districts (No. =94)

\begin{tabular}{|c|c|c|c|c|c|c|c|}
\hline \multirow[b]{2}{*}{$\begin{array}{l}\text { Cattle sold per } \\
\text { year }\end{array}$} & \multicolumn{7}{|c|}{ Number of beneficiaries (\%) } \\
\hline & $\begin{array}{l}\text { Amathole } \\
(\text { No. }=44)\end{array}$ & $\begin{array}{l}\text { OR Tambo } \\
(\text { No. }=13)\end{array}$ & $\begin{array}{l}\text { Joe Gqabi } \\
(\text { No. }=5)\end{array}$ & $\begin{array}{l}\text { Alfred Nzo } \\
(\text { No. }=13)\end{array}$ & $\begin{array}{l}\text { Chris Hani } \\
\text { (No. = 11) }\end{array}$ & $\begin{array}{l}\text { Sarah Baartman } \\
(\text { No. = 8) }\end{array}$ & $\begin{array}{l}\text { Total } \\
\text { (No. = 94) }\end{array}$ \\
\hline $1-10$ & $40(90.9)$ & $12(92.3)$ & $1(20)$ & $10(76.9)$ & $9(81.8)$ & $4(50)$ & $76(80.8)$ \\
\hline $11-20$ & $2(4.6)$ & $1(7.7)$ & $4(80)$ & $3(23.1)$ & $1(9.1)$ & $2(25)$ & $13(13.8)$ \\
\hline $20+$ & $2(4.5)$ & $0(0)$ & $0(0)$ & $0(0)$ & $1(9.1)$ & $2(25)$ & $5(5.3)$ \\
\hline
\end{tabular}

line with Molefi and Mbajiorgu (2016) and Marandure et al. (2016) who found sales to other farmers to be the most used market channel by poor-resourced farmers. The possible reason for most of the beneficiaries to use sales to other farmers could be due to their inability to sell cattle at their own determined price. According to Coetzee et al. (2006), formal marketing systems which require young and well-conditioned animals work to the disadvantage of poor-resourced farmers, as they market older and emaciated animals. The reason for this may be due to misinformation by poor-resourced farmers as they believed that cattle must be old and big to yield more profits.

Marketing constraints experienced by the beneficiaries of the Nguni Cattle Project and the support received from the government

Of the 120 interviewed beneficiaries of the Nguni Cattle Project, the most common (41.7\%) reported low cattle numbers as their main marketing constraint, followed by inability to meet formal market standards (25\%) and least with undesirable breed by the market (14.7\%) (Table 7). One of the objectives of the Nguni Cattle Project is to increase the production of communal farmers; however, low cattle numbers being reported as the main challenge means that there is a lot to be done in order to increase commercialization. There are on-going initiations by the policy-makers that the number of cattle loaned to the farmers must be topped up to 30 heifers and two bulls instead of 10 heifers and two bulls. This will speed up the commercialization initiative by dealing with the low cattle numbers' constraint. Due to the inability to meet market standards (such as required weight and age at selling and the detailed records of their cattle), the beneficiaries reported that they are willing to sell their cattle to informal markets. According to Stegmann (2012), the average weight of the mature Nguni cattle is $300-450 \mathrm{~kg}$.

About $14.7 \%$ of beneficiaries reported undesirable breed by the market as their challenge. The Nguni cattle breed is reported to have small body weight (Mapiye et al. 2010). This can be one of the reasons that Nguni cattle are not in demand by most market channels. Other constraints noted by beneficiaries were lack of transportation and lack of market information (each $8.3 \%$ of beneficiaries), while the fewest beneficiaries $(2.5 \%)$ reported market distance as their main constraint. Furthermore, the results also show that out of 120 interviewed beneficiaries, only five individuals received market assistance from the government (included transportation to the market, market information and organizing the market) while the rest (115) did not receive any market support. These results revealed a threat to the commercialization process in communal areas since the farmers are

Table 7 Perceived market challenges faced by the beneficiaries of the Nguni Cattle Project in Eastern Cape

\begin{tabular}{|c|c|c|c|c|c|c|c|}
\hline \multirow[t]{2}{*}{ Market challenges } & \multicolumn{7}{|c|}{ Number of beneficiaries (\%) } \\
\hline & $\begin{array}{l}\text { Amathole } \\
(\text { No. }=60)\end{array}$ & $\begin{array}{l}\text { OR Tambo } \\
(\text { No. }=16)\end{array}$ & $\begin{array}{l}\text { Joe Gqabi } \\
(\text { No. }=5)\end{array}$ & $\begin{array}{l}\text { Alfred Nzo } \\
(\text { No. }=14)\end{array}$ & $\begin{array}{l}\text { Chris Hani } \\
(\text { No. }=13)\end{array}$ & $\begin{array}{l}\text { Sarah Baartman } \\
(\text { No. = 12) }\end{array}$ & $\begin{array}{l}\text { Total } \\
(\text { No. }=120)\end{array}$ \\
\hline Lack of transportation & $3(4.7)$ & $1(6.3)$ & $0(0)$ & $1(7.2)$ & $2(12.5)$ & $3(25)$ & $10(8.3)$ \\
\hline $\begin{array}{l}\text { Inability to meet market } \\
\text { standards }\end{array}$ & $20(33.3)$ & $1(6.3)$ & $1(10)$ & $4(28.6)$ & $4(33.3)$ & $0(0)$ & $30(25)$ \\
\hline $\begin{array}{l}\text { Undesirable breed by } \\
\text { the market }\end{array}$ & $11(18.6)$ & $0(0)$ & $4(90)$ & $0(0)$ & $2(16.7)$ & $0(0)$ & $17(14.2)$ \\
\hline Few cattle numbers & $23(38.3)$ & $9(56)$ & $0(0)$ & $6(42.8)$ & $4(33.3)$ & $8(70)$ & $50(41.7)$ \\
\hline Market distance & $1(1.8)$ & $1(3.2)$ & $0(0)$ & $1(3.6)$ & $0(0)$ & $0(0)$ & $3(2.5)$ \\
\hline $\begin{array}{l}\text { Lack of market } \\
\text { information }\end{array}$ & $2(3.3)$ & $4(28.2)$ & $0(0)$ & $2(17.8)$ & $1(4.2)$ & $1(5)$ & $10(8.3)$ \\
\hline
\end{tabular}




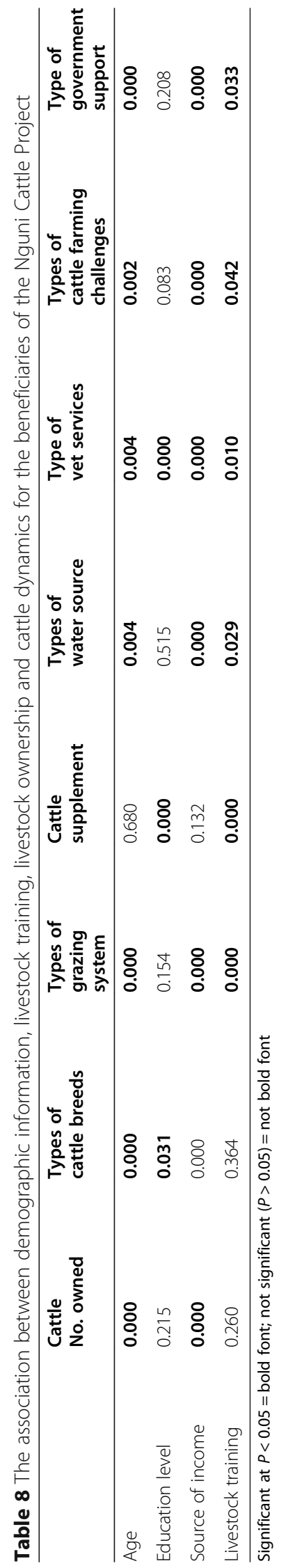




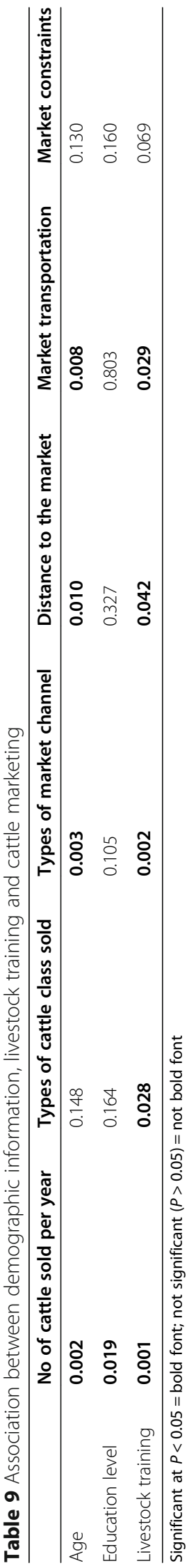


generally poor. This is due to the fact that cattle farming is one of the most important sources of income for farmers in some communal areas (Gwala et al. 2016; Molefi and Mbajiorgu 2016; Marandure et al. 2016).

\section{Association between demographic information, livestock training and cattle dynamics for the beneficiaries of the Nguni Cattle Project}

The results on the association between demographic information, livestock training, livestock ownership and cattle dynamics for the Nguni Cattle Project beneficiaries are shown in Table 8 . Beneficiary age in all six municipalities had an association with the number of cattle owned, types of cattle breed, types of grazing systems, source of water, type of veterinary services, challenges for cattle farming and types of government support. These results may be due to the fact that older people are the ones who normally have more of an interest in farming than younger ones. The reasons why younger ones are not interested in cattle farming could be attributed to lack of farming background and resources, work ethics, time, and duration of profit turnover, among others (Fuson 2016). With time, this could hamper the continuation of Nguni cattle production in rural areas if the government do not rise to make cogent policies that would encourage youth to be involved in cattle production. The results show that Alfred Nzo municipality had a significantly higher number of beneficiaries (35.7\%) with tertiary education (Table 2). The results further show that the source of income had a strong association with cattle numbers, types of cattle breeds, types of grazing systems, types of water sources, types of veterinary services, types of cattle farming challenges and types of government support. Table 2 shows that $17 \%$ of farmers reported livestock sales as their primary source of income, 53.3\% owned 11-50 number of cattle (Table 4) and $78 \%$ are selling cattle (Table 5). These results explain the significant roles played by cattle in generating income, and therefore, many farmers own large numbers of cattle to offset the market. Livestock training had a strong significant relationship with the types of grazing systems, cattle supplementation, types of water sources, types of veterinary services, types of cattle farming challenges and types of government support. These results revealed that trained farmers had the advantage of proper cattle management. This is in line with the finding of Herring et al. (2018) who reported that education and training of cattle farmers is important for fundamental animal and business management principles. However, the livestock training had no association with cattle numbers and types of breed.

\section{Association between demographic information, livestock} training and cattle marketing

The results on the association between demographic information, livestock training and cattle marketing are shown in Table 9. The age of the beneficiaries had significant association with number of cattle sold per year, types of market channel, distance to the market and market transportation. Since the majority of beneficiaries were more than 60 years old, it shows that old farmers sell their cattle to meet basic needs and also to pay children's school fees, since most of them relied on government for pensions. There was no association of education level with the marketing and constraints. This is in contrast with the study by Gwala et al. (2016) who found that education had an effect on access to services and therefore cattle production and marketing in the Eastern Cape Province of South Africa. The livestock training (such as animal nutrition, health and record keeping) obtained by the beneficiaries had a strong association with marketing and market constraints. These results show that the livestock training played a significant role in cattle marketing (Herring et al. 2018).

\section{Conclusions}

Findings from this study revealed that the Nguni Project has been successfully initiated in Eastern Cape, South Africa, to empower cattle farmers to own and retain Nguni breed cattle in their herds. The study has also shown that the majority of beneficiaries of the Nguni Project preferred to sell their cattle through private sales (i.e. to other farmers) as the main market channel without considering the record of the animal such as weight, carcass characteristics and branding mark. It was found that livestock training has significant influence on cattle production and marketing among the communal farmers. Similarly, age in all six municipalities had an association with cattle production, indicating that older people compared to youth are more involved in farming. Finally, the study reveals that low cattle numbers, diseases, feed shortage, stock theft and inability to meet market standards are the main constraints hampering the level of cattle commercialization in this communal area. It is therefore recommended that government should design critical policies that would encourage youth to participate in cattle production in order to ensure the continuity of the Nguni Project across the rural areas in Eastern Cape Province and train farmers on use of agro-industrial residue as feed stuff for cattle during drought or shortage of quality grazing areas. 


\section{Acknowledgements}

This research was supported by National Research Foundation (NRF), the Nguni Cattle Project (Project P329) and Govan Mbeki Research Development Centre (GMRDC), University of Fort Hare.

\section{Authors' contributions}

$\mathrm{NM}$ and $\mathrm{ABF}$ conceptualized and designed the work; NM and ABF collected and analysed the data; NM, ABF and EMI wrote the paper. The authors read and approved the final manuscript.

\section{Funding}

Govan Mbeki Research Development Centre (GMRDC) for funding and support the study.

\section{Availability of data and materials}

Kindly contact the author for data requests.

\section{Ethics approval and consent to participate}

Ethical principles were taken into consideration during the study to adhere to the national and international standards governing research of this nature with regards to the use of research tools.

\section{Consent for publication}

Not applicable.

\section{Competing interests}

None declared by the authors.

\section{Author details}

'Department of Livestock and Pasture Science, University of Fort Hare, Alice, Eastern Cape 5700, South Africa. ${ }^{2}$ Grootfontein Agricultural Development Institute, Middelburg, Eastern Cape 5900, South Africa. ${ }^{3}$ Department of Animal Science, Adekunle Ajasin University, Akungba-Akoko, Ondo State, Nigeria. ${ }^{4}$ Agricultural and Rural Development Research Institute, University of Fort Hare, Private Bag X1314, Alice 5700, South Africa.

Received: 7 July 2020 Accepted: 4 November 2020 Published online: 27 January 2021

\section{References}

Bahta, S.T., and S. Bauer. 2007. Analysis of the determinants of market participation within the South African small scale livestock sector. Tropentag Paper, utilisation of diversity in land use systems: sustainable and organic approaches to meet human needs. https://pdfs.semanticscholar.org/6a13/d15 aa37ca323725325c1b766d7843eb93f49.pdf. [14 August 2019].

Bester, J., L.E. Matjuda, J.M. Rust, and H.J. Fourie. 2001. The Nguni: a case study. Private Bag X2, Irene, 0062, South Africa: Animal Improvement Institute.

Coetzee, L., B.D. Montshwe, and A. Jooste. 2006. The marketing of livestock on communal lands in the Eastern Cape Province: Constraints, challenges and implications for the extension services. South African Journal of Agriculture and Extension 34: 81-103 https://www.ajol.info/index.php/sajae/article/ view/3680.

Department of Agriculture Forestry and Fisheries (DAFF). 2018. A profile of the South African Beef Market Value Chain. South Africa: Arcadia Pretoria. www. nda.gov.za. [06 July 2019].

Ellery, W.N., R.J. Scholes, and M.C. Scholes. 1995. The distribution of sweetveld and sourveld in South Africa's grassland biome in relation to environmental factors. African Journal of Range \& Forage Science 12: 38-45. https://doi.org/ 10.1080/10220119.1995.9647860.

Enkono, S.G., S.K. Kalundu, and B. Thomas. 2013. Analysis of factors influencing cattle off-take rate and marketing in Ndiyona constituency of Kavango region, Namibia. Journal of Agricultural Extension and Rural Development 5 : 201-206. https://doi.org/10.5897/JAERD2013.0501.

Eugene, M. 2017. Characterization of cattle production systems in Nyagatare District of Eastern Province, Rwanda. Rheology: Open Access. 1: 107-128.

Fuller, A. 2006. The sacred hide of Nguni; the rise of an ancient breed of cattle is giving South Africa new opportunity. Miracles that are changing the nation. Newsletter. South Africa: Industrial Development Corporation (IDC). pp. 3-4.

Fuson, LE. 2016. Reasons youth choose or do not chose to be involved in 4-H livestock projects in Tennessee. Knoxville: University of Tennessee, TRACE:
Tennessee Research Tennessee Research and Creative Exchange. https:// trace.tennessee.edu.uk.

Gwala, L., N. Monde, and V. Muchenje. 2016. Effect of agricultural extension services on beneficiaries of the Nguni cattle project in the Eastern Cape Province, South Africa: A case study of two villages. Applied Animal Husbandry and Rural Development 9: 31-40 www.sasas.co.za/aahrd/.

Hangara, G.N., M.Y. Teweldemedhin, and I.B. Groenewald. 2011. Major constraints for cattle productivity and managerial efficiency in communal areas of Omaheke Region, Namibia. International Journal of Agricultural Sustainability 9: 495-507. https://doi.org/10.1080/14735903.2011.603516.

Herring, A.D., A.T. Kyaw, and T. Khaing. 2018. Beef cattle production system capacity considerations for improved food security: A case study in Myanmar. Animal Frontiers 8: 38-46. https://doi.org/10.1093/af/vfy010.

Everatt, D., N. Dube, and M. Ntsime. 2004. Integrated Sustainable Rural Development Strategy (ISRDS): nodal review. Johannesburg: University of Witwatersrand. hptts://doi.org/10.13140/RG.2.2.21250.07360. [4 June 2019].

Kirsten, J., and W. Sihlobo. 2019. Is South African agriculture really dominated by big commercial farms? Evidence suggests not. South Africa: News 24, Breaking News First. 2019-02-27. https:/www.news24.com/Analysis/is-south-africanagriculture-really-dominated-by-big-commercial-farms-evidencesuggestsnot-20190227. [14 July 2019].

Lapar, M.L., G. Holloway, and S. Ehui. 2003. Policy options promoting market participation of smallholder livestock producers: A case study from the Philippines. Food Policy 28: 187-211. https://doi.org/10.1016/S03069192(03)00017-4.

Maburutse, B.E., T. Mutibvu, D.T. Mbiriri, and M.T. Kashangura. 2012. Communal livestock production in Simbe, Gokwe South District of Zimbabwe. Online Journal of Animal and Feed Research 2: 351-360 http://www.science-line. com/index/; http://www.ojafr.ir.

Mapiye, C., M. Chimonyo, K. Dzama, J.G. Raats, and M. Mapekula. 2009. Opportunities for improving Nguni cattle production in the smallholder farming system of South Africa. Livestock Science 124: 196-204. https://doi. org/10.1016/j.livsci.2009.01.013.

Mapiye, C., M. Chimonyo, K. Dzama, P.E. Strydom, and V. Muchenje. 2010. Meat quality of Nguni steers supplemented with Acacia karroo leaf-meal. Meat Science 84: 621-627. https://doi.org/10.1016/..meatsci.2009.10.021.

Mapiye, C., M. Chimonyo, V. Muchenje, K. Dzama, M.C. Marufu, and J.G. Raats. 2007. Potential for value-addition of Nguni cattle products in the communal areas of South Africa: A review. African Journal of Agricultural Research 2: 488-495.

Marandure, T., C. Mapiye, G. Makombe, B. Nengovhela, P. Strydom, V. Muchenje, and K. Dzama. 2016. Determinants and opportunities for commercial marketing of beef cattle raised on communally owned natural pastures in South Africa. African Journal of Range Forage Science 33: 199-206. https://doi. org/10.2989/10220119.2016.1235617

Mashoko, E., V. Muchenje, T. Ndlovu, C. Mapiye, M. Chimonyo, and L. Musemwa. 2007. Beef cattle production in a peri-urban area of Zimbabwe. Journal of Sustainable Development 9: 121-132 http://www.ssd-africa.com/Jsda/V9n4 Winter2007/PDF/BeefCattleP.pdf.

Masikati, P. 2011. Improving the water productivity of integrated crop-livestock systems in the semi-arid tropics of Zimbabwe: an ex-ante analysis usingsimulation modeling. A Ph.D. Thesis. Germany: University of Bonn. http://hss.ulb.uni-bonn.de/2011/2463/2463.pdf. [26 October 2019].

Mavedzenge, B.Z. J. Mahenehene, F. Murimbarimba, I. Scoones, W. Wolmer, and C. Hotel. 2006. Changes in the livestock sector in Zimbabwe following land reform: the case of Masvingo Province. Mokoro Ltd, The Old Music Hall, 106108 Cowley Road, Oxford, OX4 1JE, United Kingdom Website. http://mokoro. co.uk/land-rights-article/changes-in-the-livestock-sector-in-zimbabwefollowing-land-reform-the-case-of-masvingo-province-a-report-of-adiscussionworkshop/. [17 June 2019].

Molefi, S.H., and C.A. Mbajiorgu. 2016. Assessing the potential of beef cattle farming as contributor to income of communal households of Chief Albert Luthuli municipality in Mpumalanga province, South Africa. Indian Journal of Animal Research 51. https://doi.org/10.18805/ijar.9552.

Muchenje, V., K. Dzama, M. Chimonyo, J.G. Raats, and P.E. Strydom. 2008a. Meat quality of Nguni, Bonsmara and Angus steers raised on natural pasture in the Eastern Cape, South Africa. Meat Science 79: 20-28. https://doi.org/10.1016/j. meatsci.2007.07.026.

Muchenje, V., K. Dzama, M. Chimonyo, J.G. Raats, and P.E. Strydom. 2008b. Tick susceptibility and its effects on growth performance and carcass characteristics of Nguni, Bonsmara and Angus steers raised on natural pasture. Animal 2: 298-304. https://doi.org/10.1017/S1751731107001036. 
Mucina, L., and M.C. Rutherford. 2006. The vegetation of South Africa, Lesotho and Swaziland. Strelitzia 19. Pretoria: South African Biodiversity Institute. https://www.sanbi.org/wp-content/uploads/2018/05/Strelitzia-19.pdf. [20 July 2019].

Mueller, J.P., B. Rischkowsky, A. Haile, J. Philipsson, O. Mwai, B. Besbes, A. Valle Zárate, M. Tibbo, T. Mirkena, G. Duguma, J. Sölkner, and M. Wurzinger. 2015. Community-based livestock breeding programmes: Essentials and examples. Journal of Animal Breeding and Genetics 132: 155-168. https://doi.org/10. $1111 /$ jbg.12136

Musemwa, L., A. Mushunje, M. Chimonyo, G. Fraser, C. Mapiye, and V. Muchenje. 2008. Nguni cattle marketing constraints and opportunities in the communal areas of South Africa: Review. African Journal of Agricultural Research 3: 239 245 http://www.academicjournals.org/AJAR.

Musemwa, L., A. Mushunje, M. Chimonyo, and C. Mapiye. 2010. Low cattle market off-take rates in communal production systems of South Africa: Causes and mitigation strategies. Journal of Sustainable Development in Africa 12: 209226 Low_Cattle_Market_off-take_rates_in_comm20151124-5979-zm1q7v.pdf.

Ndebele, J.J., V. Muchenje, C. Mapiye, M. Chimonyo, L. Musemwa, and T. Ndlovu. 2007. Cattle breeding management practices in the Gwayi smallholder farming area of South-Western Zimbabwe. Livestock Research for Rural Development 19 http://www.Irrd.org//rrd19/12/ndeb19183.htm.

Ndlovu, T., M. Chimonyo, A.I. Okoh, V. Muchenje, K. Dzama, and S. Dube. 2009. A comparison of nutritional-related blood metabolites among Nguni, Bonsmara and Angus steers raised on sweetveld. Veterinary Journal 179: 273-281. https://doi.org/10.1016/j.tvjl.2007.09.007.

Nkonki-Mandleni, B., F.T. Ogunkoya, and A.O. Omotayo. 2019. Socioeconomic factors influencing livestock production among smallholder farmers in the Free State Province of South Africa. International Journal of Entrepreneurship 23: 1-17 5c65c470299bf1d14cc75995.

Pica-Ciamarra, U., L. Tasciotti, J. Otte, and A. Zezza. 2011. Livestock assets, livestock income and rural households: Evidence from household surveys. Rome: FAO http://documents.worldbank.org/curated/en/101271468151472539/Livestockassets-livestock-income-and-rural-households-cross-country-evidence-fromhousehold-surveys. [14 June 2019].

Raats, J.G., A.M. Magadlela, G.C.G. Fraser, and A. Hugo. 2004. 'Re-introducing Nguni nucleus herds in 100 communal villages of the Eastern Cape Province'. A proposed co-operative project between the University of Fort Hare, Agricultural and Development Research Institute (ARDRI) and the Eastern Cape Department of Agriculture and the Kellogg Foundation. South Africa.

Statistics South Africa (STATS SA). 2016. Community survey. Agricultural households. Republic of South Africa: Department: Statistics South Africa. http://www. statssa.gov.za/publications/03-01-05/Presentation CS2016 Agricultural Households.pdf. [20 August 2019].

Stegmann, M. 2012. Production potential of Nguni crosses. South Africa: Farmer's weekly. http://www.ngunicattle.info/Publications/Journals/2012/ Production\%20potential\%20of\%20Nguni\%20Crosses\%20v2.pdf. [06 July 2019].

Tada, O., V. Muchenje, J. Madzimure, and K. Dzama. 2013. Determination of economic weights for breeding traits in indigenous Nguni cattle under insitu conservation. Livestock Science 155: 8-16. https://doi.org/10.1016/j.livsci. 2013.04.011.

Tavirimirwa, B., R. Mwembe, B. Ngulube, N.Y.D. Banana, G.B. Nyamushamba, S. Ncube, and D. Nkomboni. 2013. Communal cattle production in Zimbabwe: A review. Livestock Research for Rural Development 25: 12. https://doi.org/10. 13140/2.1.3412.8009.

Tonamo, A., B. Tamir, G. Goshu, and E. Belete. 2015. Characterization of cattle husbandry practices in Essera Woreda, Dawuro Zone, Southern Ethiopia. African Journal of Agricultural Research. 10: 3421-3435. https://doi.org/10. 5897/AJAR2015.9939.

\section{Publisher's Note}

Springer Nature remains neutral with regard to jurisdictional claims in published maps and institutional affiliations.

\section{Submit your manuscript to a SpringerOpen ${ }^{\circ}$ journal and benefit from:}

- Convenient online submission

- Rigorous peer review

- Open access: articles freely available online

- High visibility within the field

- Retaining the copyright to your article

Submit your next manuscript at $\boldsymbol{\nabla}$ springeropen.com 